\title{
The Problems of Ideas in the Muslim World
}

By Malik Bennabi, trans. and annotated by Mohamed Tahir al-Messawi, Budaya Ilmu sdn., Bhd, Malaysia: Dar al Hadara.

This is a good English translation of a slim volume originally published in French under the title, Le Probleme des Ideas dans le Monde Musulman. The book is composed of 17 essays, the culmination of the intellectual life of its author, the late Malik Bennabi.

The book insightfully deals with a problem heretofore neglected by most authorities on Islamic thought: the problem of ideas in the Muslim world. The central theme of the book builds on the close linkage between ideas and their cultural environment, which determines whether ideas are dead, deadly, or efficient. As an original thinker, Bennabi identifies the problem of the Muslim world as civilizational and cultural in nature. Bennabi's contribution to modem Muslim thought lies, in principle, in his attempt to discover the universal laws that govem the performance of human civilization from birth, growth, prosperity, expansion, decline, and disintegration and to apply these laws to the history of ideas in the Muslim world. He postulates that the social process takes its course in the history of civilizations and cultures, revealing itself in the 
dynamics of three major realms: persons, objects, and ideas, the latter being the focus of his book.

Bennabi perceives the post-Muwahid or postcivilized Muslim world as lacking the spirit of creativity and falling into a process of ad hoc borrowing of ready-made objects and ideas from the West without due concern for the preconditions of their viability and applicability. In order to analyze this situation, the author develops a framework of analysis by which regional issues and minute details find their place and acquire their significance within a comprehensive and integrated whole, which in itself poses a real challenge to the paradigm currently dominating the realm of ideas in the Muslim world.

Instead of concentrating on the economic aspects of the problem of development and modernization in the Muslim world, Bennabi concentrates on the problem of the deficiency of ideas. This deficiency manifests itself in the way a society cannot utilize the means already at hand or create new concepts. In this regard, Bennabi remarks that this is the logical answer to why most fertile lands in many Muslim countries have not enabled them to realize their economic take-off from the primary to the secondary stage of economic development. The Muslim world is still captured in the realms of objects and persons and has yet to enter the realm of ideas.

For a great historical and civilizational transformation to take place in the Muslim world, this transformation must be related to "ideas-force": it must be a product of a fundamental idea which derives from the (primitive) Muslim world and allows it to construct a new system of ideas in connection and in accordance with that archetype. Without that the Muslim world will continue to limit itself to the realms of objects and persons.

Bennabi identifies the realm of persons as a situation in which the worshiped leader, "Zaim," no longer represents the image of an example or "prototype." Whenever that kind of idea disappears, the idol, or the idea-person, prevails.

Ideas should not be replaced by objects or persons. They must be independent of all kinds of idols. They should also be efficacious. It is necessary for them to be genuine, but even genuine ideas may lose or find their efficacy in the course of history. For example, the notion of the bloodstream, which was discovered by Ibn al-Nafis in the twelfth century, could not commence its scientific career until it was implemented in the seventeenth century by William Harvey. The lesson extracted from this example is that in order for Islamic ideas to be efficacious in the present dynamic societies, they have to recover their original efficacy and to resume their position among the ideas that make history.

Bennabi stresses the importance of providing Islamic ideas with what enables them to stand up to the spirit of the age. To him this does not imply 
making any concessions to the profane at the expense of the sacred, but only to liberate Muslims from cerain vanities of sufficiency which might be fatal for them. These are dead ideas and deadly ideas. The dead ideas are those which were born at the miracles of Qurawiyyin, Zaytuna, and Al-Azhar during the post-Muwahid centuries. They were deprived of their roots in the original cultural plasma and of the Muslim world blindly adopted by the traditional 'ulama. They are not efficient any more. Deadly ideas are those which have left the roots in their original cultural universe when they came into our Muslim culture. It is sometimes the same individual who absorbs them both. The hereditary vins, in a way, absorbs the alien microbe for the dead ideas attract and invite the deadly ones.

The Muslim world blew off course with ideas which put it face-to-face with a technological civilization without establishing real contact with the civilization's roots. On the other hand, these are the ideas which link it to its original cultural universe without embracing the archetype of their universe, despite the praiseworthy effort made by reformers.

Upon concluding his comprehensive and rigorous analysis of the cultural and political aspects of the problem of ideas, Bennabi determines that the Muslim world can never make history by simply following in another's footsteps. It has to create its own ideas. This is the challenge for the new breed of "ulama and refomers.

In this boldly conceived and vigorously argued volume, Bennabi has successfully taken us further in confronting the critical problem of ideas than we have ever been taken before by Muslim authors. In fact, this is a work of the very highest imporance to those who are concerned with studying the dynamics of the Islamic movement and its capacity to stimulate further thought, which is the preeminent measure of that imporance.

Mohamed Wagialla Ahmed Department of Political Science Omdurman Islamic University 